\section{Effect of cadmium stress on seed germination, plant growth and hydrolyzing enzymes activities in mungbean seedlings}

\author{
Sumera Anwar ${ }^{1} \mathbb{D}$, Fahad Shafiq ${ }^{1}{ }^{\mathbb{D}}$, Zaib-un-Nisa $^{1} \mathbb{D}$, Uzma Usman $^{1}{ }^{\mathbb{D}}$, \\ Muhammad Yasin Ashraf ${ }^{1 *}$ (D) Naila Ali $^{1}$ iD
}

ABSTRACT: Both protein and starch hydrolysis contribute to the effective mobilization of seed reserves to trigger seed germination. We studied the activities of hydrolytic enzymes in germinating seeds of mung bean (Vigna radiata) exposed to cadmium stress at $0,25,50,75$, $100 \mathrm{mg} . \mathrm{L}^{-1}$. Exposure to $\mathrm{Cd}$ stress decreased the seed germination rate and early seedling growth traits, including root and shoot length and plant fresh and dry biomass compared to control. The adverse effects of $\mathrm{Cd}$ were more prominent in terms of shoot length than root length. Seedling $\alpha$-amylase and protease activities exhibited significant reductions with increasing $\mathrm{Cd}$ dose. We also recorded $\mathrm{Cd}$-induced reduction in total soluble proteins and sugars while the concentration of free amino acids exhibited an increase. Above all, a decrease in the hydrolysis process of reserve carbohydrates, proteins and impaired reserve translocation contributed to the inhibition of seedlings' germination and early growth traits.

Index terms: $\alpha$-amylase, cadmium stress, hydrolyzing enzymes, protease.

RESUMO: Tanto a hidrólise de proteínas quanto de amido contribui para a mobilização eficaz das reservas para desencadear a germinação das sementes. Estudamos a atividade de enzimas hidrolíticas na germinação de sementes de feijão mungo (Vigna radiata) expostas ao estresse de cádmio a $0,25,50,75,100 \mathrm{mg}^{\mathrm{L}^{-1}}$. A exposição ao estresse por Cd diminuiu a taxa de germinação das sementes e as características de crescimento inicial das plântulas, incluindo comprimento de raiz e parte aérea e biomassa fresca e seca da planta em comparação com o controle. Os efeitos adversos do $\mathrm{Cd}$ foram mais evidentes no comprimento do caule do que no comprimento da raiz. As atividades de $\alpha$-amilase e protease de plântulas exibiram reduções significativas com o aumento da dose de $\mathrm{Cd}$. Também observamos redução induzida por $\mathrm{Cd}$ em proteínas solúveis totais e açúcares, enquanto a concentração de aminoácidos livres exibiu um aumento. Em síntese, uma diminuição no processo de hidrólise de carboidratos de reserva, proteínas e translocação de reserva prejudicada contribuiu para a inibição da germinação das mudas e características de crescimento inicial.

Termos para indexação: $\alpha$-amylase, estresse por cádmio, enzimas hidrolíticas, protease.
Journal of Seed Science, v.43, e202143042, 2021

http://dx.doi.org/10.1590/ 2317-1545v43256006 


\section{INTRODUCTION}

In cereals, endosperm development and its physiological roles have been well documented. Initially, the embryo scutellum synthesizes and secrete gibberellin, a germination-promoting hormone, into the aleurone layer of the endosperm. It ultimately enhances the synthesis of hydrolytic enzymes in the aleurone layer (Yan et al., 2014). Hydrolytic enzymes such as $\alpha$-amylase, protease, and acid phosphatases accelerate the process of seed germination and seedlings' establishment. However, the presence of heavy metals leads to a reduction in the activities of these enzymes in barley seeds (Kalai et al., 2014; Sanal et al., 2014).

Cadmium ( $\mathrm{Cd}$ ) is well known to constrain seed germination rates via different mechanisms such as impairment of water uptake in seeds which ultimately limits the water availability for embryo development (Vijayaragavan et al., 2011). However, inadequate water supply is not the only constraint for the germination phase. Inhibition of starch mobilization is another process in endosperm affected by $\mathrm{Cd}$, which causes impaired translocation of sugars towards the developing embryonic axis and ultimately results in starvation of the developing embryo (Kuriakose and Prasad, 2008). In Sorghum bicolor seeds, reduction in hydrolyzing enzyme activities such as in acid phosphatase, $\alpha$-amylase, and protease has been reported under $C d$ stress which suggests a reduction in the storage mobilization process. Furthermore, a reduction of $\alpha$-amylase activity has been observed, which reduced starch release from cotyledons (Kalai et al., 2016). He et al. (2010) further clarified that, as Ca is a vital component for $\alpha$-amylase activity; therefore, substituting $\mathrm{Ca}$ with $\mathrm{Cd}$ ion could interrupt amylase functioning. $\mathrm{Cd}$ stress also induces the accumulation of malondialdehyde contents in some cereals such as Oryza sativa and Triticum aestivum, which indicates membrane damage (Qin et al., 2020). The leakage of amino acids and soluble sugars due to loss of membrane integrity is another indication of alteration in the remobilization process observed in seeds of Vicia faba and Pisum sativum (Rahoui et al., 2010b; Basahi, 2021).

Mungbean (Vigna radiata L.) is an important legume species that contributes a special part to the human diet. Some available reports showed the sensitivity of $V$. radiata towards $C d$ stress, as $C d$ application decreases the root and shoot growth, leaf area, and dry biomass content of mungbean as well as cause genotoxicity and oxidative stress in mungbean seedlings (Hassan et al., 2021). Further, Cd stress disturbs the water status in leaves, stomatal regulation, nitrogen-fixing ability, and abscisic acid content in mungbean (Ghani, 2010). Therefore, in this study, we investigated the effect of cadmium stress on seed germination, biomass, metabolites, and activities of some hydrolyzing enzymes such as $\alpha$-amylase and protease were investigated.

\section{MATERIALS AND METHODS}

\section{Plant material and stress treatments}

The experiment was carried out in small plastic pots ( $12 \mathrm{~cm}$ diameter) containing sand. The pots were placed in the wire house of the Nuclear Institute for Agriculture and Biology Faisalabad, during winter 2018 under natural conditions. Ten seeds of the mungbean (Vigna radiata L.) cultivar (NM-11) were sown in each pot, and different concentrations of $\mathrm{Cd}\left(0,25,50,75\right.$, and $\left.100 \mathrm{mg} \cdot \mathrm{L}^{-1}\right)$ were applied using anhydrous $\mathrm{CdCl}_{2}$. Each treatment has three replications. The five germinating seeds were removed after $24,48,72,96$, and $120 \mathrm{~h}$ of $\mathrm{Cd}$ treatments from each pot to determine enzyme activities, reducing, non-reducing sugars, total soluble protein, and total free amino acids. While the rest of the seedlings were harvested after two weeks of treatment for the determination of growth attributes such as root lengths $(\mathrm{cm})$, shoot lengths $(\mathrm{cm})$, fresh weight/plant $(\mathrm{g})$, and dry weight/plant $(\mathrm{g})$ of root and shoot.

\section{Determination of $\alpha$-amylase activity}

The seedlings material $(1 \mathrm{~g})$, frozen in liquid nitrogen, was homogenized in $10 \mathrm{~mL}$ phosphate buffer (pH 7.2), extracted with cold $1 \% \mathrm{NaCl}$, and centrifuged at $4000 \mathrm{rpm}$ for 30 minutes. The supernatant was used to determine the 
enzyme activity according to the method reported by Chrispeels and Varner (1967). The enzyme activity was calculated as $\mathrm{mg}$ of starch hydrolyzed $\mathrm{g}^{-1}$.fresh weight. $\mathrm{h}^{-1}$.

\section{Determination of protease activity}

Protease activity was determined as described by Ainouz (1970). For this purpose, $1 \mathrm{~g}$ seedlings were homogenized and extracted with chilled $1 \% \mathrm{NaCl}$ in $0.2 \mathrm{M}$ phosphate buffer $(\mathrm{pH} 7.5)$, centrifuged at $12000 \mathrm{rpm}$ for 30 minutes. $1 \mathrm{~mL}$ of supernatant and $5 \mathrm{~mL}$ of $1 \%$ casein solution were incubated at $50{ }^{\circ} \mathrm{C}$ in $0.2 \mathrm{M}$ sodium phosphate buffer (pH 6.0). For termination of the reaction, $1 \mathrm{~mL}$ of $40 \%$ TCA was added after 60 minutes (Ainouz, 1970). The proteolytic activity was measured at $570 \mathrm{~nm}$ in TCA soluble fraction after reaction with the Folin Phenol reagent (Lowry et al., 1951).

\section{Estimation of reducing and non-reducing sugars}

For the estimation of sugars, one gram of seedlings was ground in $10 \mathrm{~mL}$ of $80 \%$ ethanol, filtered, and used for estimation of total sugars, reducing sugars, and non-reducing sugars. Total soluble sugars were estimated by the phenol-sulphuric acid method using glucose as standard (Dubois et al., 1956). Reducing sugars were estimated by 3,5-dinitrosalicylic acid method (DNSA) using glucose as standard (Miller, 1959) with a slight modification (Krivorotova and Sereikaite, 2014). DNSA reagent was prepared by dissolving $1 \mathrm{~g}$ of DNSA and $30 \mathrm{~g}$ of sodium-potassium tartaric acid in $80 \mathrm{~mL}$ of $0.5 \mathrm{~N} \mathrm{NaOH}$ at $45^{\circ} \mathrm{C}$. After dissolution, the solution was cooled down to room temperature and diluted to $100 \mathrm{~mL}$ with the help of distilled water. For the measurement, $1 \mathrm{~mL}$ of plant extract was mixed with $2 \mathrm{~mL}$ of DNSA reagent in a test tube and kept at $95{ }^{\circ} \mathrm{C}$ for $5 \mathrm{~min}$. After cooling, $7 \mathrm{~mL}$ of distilled water was added to the solution and the absorbance was measured at $540 \mathrm{~nm}$ using a UV-VIS spectrophotometer. The reducing sugar content was calculated from the calibration curve of D-glucose, and the results were expressed as $\mathrm{mg} \mathrm{D}$-glucose equivalent per gram fresh weight. Non-reducing sugars were expressed as difference between total sugars and reducing sugars.

\section{Proteins and free amino acids analysis}

Total soluble proteins were determined using the method of Lowry et al. (1951). Seedlings (1.0 g) were ground in $10 \mathrm{~mL}$ of $0.2 \mathrm{M}$ phosphate buffer $(\mathrm{pH} \mathrm{7.0)}$ and filtered via nylon cloth. The plant filtrate was precipitated with $10 \%$ TCA in equal volume, centrifuged at 10,000 rpm for 5 minutes. The protein was assessed after resuspension of the pellet with $0.1 \mathrm{~mol} \mathrm{NaOH} \mathrm{dm}^{-3}$. Total proteins $(\mathrm{mg} / \mathrm{g}$ ) were calculated using the standard curve of Bovine Serum Albumin (BSA) solution (Bradford, 1976). Total free amino acids were determined by following the ninhydrin method described by Hamilton et al (1943). For this purpose, $1 \mathrm{~mL}$ plant extract was mixed with $1 \mathrm{~mL}$ of $10 \%$ and $1 \mathrm{~mL}$ of $2 \%$ ninhydrin solutions. The OD was read at $570 \mathrm{~nm}$ using a spectrophotometer and values of amino acids ( $\mathrm{mg} / \mathrm{g}$ fresh weight) were calculated using the standard curve of Leucine solution.

\section{Statistical analysis}

The data were statistically analyzed using the analysis of variance (ANOVA). The Fisher's Least Significant Difference test at a $5 \%$ probability level was used to assess the differences among significant means. The associations between variables were determined by computing Pearson correlation coefficients using the XLSTAT add-in of Microsoft Excel.

\section{RESULTS AND DISCUSSION}

\section{Effect of cadmium stress on germination and morphological attributes}

Cadmium stress significantly decreased all the growth (germination rate, root and shoot length, fresh mass, dry mass) parameters (Table 1). It was observed that the highest supplementation of $\mathrm{Cd}\left(100 \mathrm{mg} \cdot \mathrm{L}^{-1}\right)$ caused maximum damage to plants and decreased the germination percentage (27\%), shoot length (63\%), and root length (27\%) as compared to control $\left(0 \mathrm{mg} . \mathrm{L}^{-1}\right)$ plants. Further, $100 \mathrm{mg} \mathrm{Cd.L}^{-1}$ application displayed a significant decrease in shoot and 
Table 1. The effect of $\mathrm{Cd}$ and time of application of $\mathrm{Cd}$ on the germination rate and morphological traits of germinating seedlings of Vigna radiata.

\begin{tabular}{cccccccc}
\hline $\mathrm{CdCl}_{2}$ & $\begin{array}{c}\text { Germination } \\
\text { rate (\%) }\end{array}$ & $\begin{array}{c}\text { Shoot } \\
\text { length }(\mathrm{cm})\end{array}$ & $\begin{array}{c}\text { Root length } \\
(\mathrm{cm})\end{array}$ & $\begin{array}{c}\text { Shoot fresh } \\
\text { weight }(\mathrm{g})\end{array}$ & $\begin{array}{c}\text { Root fresh } \\
\text { weight }(\mathrm{g})\end{array}$ & $\begin{array}{c}\text { Shoot dry } \\
\text { weight }(\mathrm{g})\end{array}$ & $\begin{array}{c}\text { Root dry } \\
\text { weight }(\mathrm{g})\end{array}$ \\
\hline $0 \mathrm{mg} \cdot \mathrm{L}^{-1}$ & $93.0 \mathrm{a}$ & $8.53 \mathrm{a}$ & $11.65 \mathrm{a}$ & $0.63 \mathrm{a}$ & $0.36 \mathrm{a}$ & $0.46 \mathrm{a}$ & $0.09 \mathrm{a}$ \\
$25 \mathrm{mg} \cdot \mathrm{L}^{-1}$ & $79.0 \mathrm{ab}$ & $4.02 \mathrm{~b}$ & $8.82 \mathrm{ab}$ & $0.63 \mathrm{a}$ & $0.33 \mathrm{ab}$ & $0.30 \mathrm{~b}$ & $0.06 \mathrm{~b}$ \\
$50 \mathrm{mg} \cdot \mathrm{L}^{-1}$ & $75.0 \mathrm{~b}$ & $3.64 \mathrm{c}$ & $9.43 \mathrm{~b}$ & $0.55 \mathrm{~b}$ & $0.29 \mathrm{~b}$ & $0.28 \mathrm{~b}$ & $0.05 \mathrm{~b}$ \\
$75 \mathrm{mg} \cdot \mathrm{L}^{-1}$ & $70.0 \mathrm{c}$ & $3.55 \mathrm{c}$ & $9.92 \mathrm{c}$ & $0.47 \mathrm{~b}$ & $0.18 \mathrm{c}$ & $0.25 \mathrm{~b}$ & $0.02 \mathrm{c}$ \\
$100 \mathrm{mg} \cdot \mathrm{L}^{-1}$ & $67.1 \mathrm{c}$ & $3.09 \mathrm{~d}$ & $8.39 \mathrm{c}$ & $0.45 \mathrm{c}$ & $0.14 \mathrm{c}$ & $0.22 \mathrm{~b}$ & $0.01 \mathrm{~d}$ \\
\hline
\end{tabular}

root fresh mass by $28 \%$ and $61 \%$, respectively, compared to non-treated plants. Root and shoot dry biomass also exhibited the same pattern and showed a 2-fold and 9-fold decline, respectively, under Cd treatment (100 mg. $\left.\mathrm{L}^{-1}\right)$ than control. The reduction in germination rates can be described by a decrease in metabolic and physiological activities such as a reduced movement of water and reserves towards the embryonic axis (Vijayaragavan et al., 2011). Further, Rahoui et al. (2010a) reported delays in germination when the seeds of pea and faba beans were contaminated with $\mathrm{Cd}$ due to membrane damage and solutes leakage.

Shoot and root lengths are important elements for any plant to transport nutrients and water. The results included in Table 1 show that both shoot and root length of mungbean seedlings were adversely affected by Cd treatment compared to non-stressed plants. However, data showed that shoot length (52\%-63\% decrease) was affected more than root growth ( $14 \%$ to $24 \%$ decrease) under the Cd stress. Intriguingly, Cd stress at $25 \mathrm{mg} . \mathrm{L}^{-1}$ decreased the root length by $24 \%$, while a $19 \%$ decrease in root length was observed at $50 \mathrm{mg} \cdot \mathrm{L}^{-1}$ and $75 \mathrm{mg} . \mathrm{L}^{-1} \mathrm{Cd}$ treatments. Thus, it shows that root length showing some degree of tolerance to $\mathrm{Cd}$ treatments. Due to the mobile nature, $\mathrm{Cd}$ enters into plants through roots and is further translocated towards shoots via different transporters of xylem and phloem in an ionic form. Both apoplastic and symplastic transport pathways are used for the entry of $\mathrm{Cd}$ into the xylem, then it is loaded to vessel elements or tracheids of the stele and ultimately translocated to the shoot (Dong et al., 2019). It indicates that the sensitivity of growth parameters to $\mathrm{Cd}$ stress varied with species, genotypes, and cultivars. Further, a significant decline in fresh and dry biomass of mungbean seedlings was observed under increasing $\mathrm{Cd}$ concentrations. These growth losses might be due to impairment of PSII activity, inhibition of cell division as well as direct or indirect inhibition of different physiological processes like photosynthesis, respiration, and plant-water relation, which ultimately renders the activity of cell and leads to poor growth and plant biomass as reported by (Rahoui et al., 2010a; Vijayaragavan et al., 2011; Irfan et al., 2014).

\section{Effect of cadmium stress on $\alpha$-amylase activity and sugar contents}

Cadmium stress had a pronounced effect on the activity of $\alpha$-amylase and other associated changes (sugar contents) in mungbean (Figure 1a). Cadmium contamination significantly reduced the $\alpha$-amylase activity of mungbean seeds

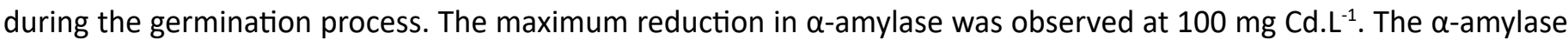
activity was decreased by $75,419,122,204$, and $121 \%$ as compared to their control at $24,48,72,96$, and $120 \mathrm{~h}$ respectively. At 25, 50, and $75 \mathrm{mg} \mathrm{Cd.L}^{-1}$ stress the maximum reduction in $\alpha$-amylase activity was observed at $96 \mathrm{~h}$ after

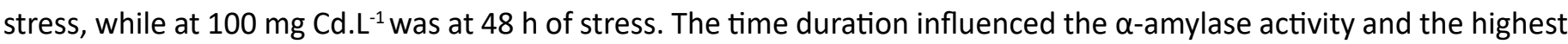
activity was observed at 120 hours while the lowest at 24 hours under control $\left(0 \mathrm{mg} \cdot \mathrm{L}^{-1}\right)$ at different concentrations of $\mathrm{Cd}$ stress. The statistical analyses indicated that the $\mathrm{Cd}$ treatment and time duration interaction was non-significant.

The $\alpha$-amylase synthesized de novo during the germination process and its activity plays a major role in the starch degradation process during the germination process in cereal grains. We observed a significant reduction in $\alpha$-amylase activity in Cd-treated mungbean seedlings. Similarly, Kuriakose and Prasad (2008) also reported a considerable 
decreased in $\alpha$-amylase activity in embryonic axes and seeds of Sorghum bicolor under $\mathrm{Cd}(0.5 \mathrm{mM})$ stress. However, $\alpha$-amylase activity showed an increasing pattern with time and showed maximum values after $120 \mathrm{~h}$. Similar effects of $\mathrm{Cd}$ stress on seedling growth and seed amylase activities were reported in rice (He et al., 2008). Reduction in $\alpha$-amylase activity disturbs the process of starch breakdown which ultimately decreases germination and growth (Kaur et al., 2001). Secondly, amylase activity requires calcium ions, therefore reduce $\alpha$-amylase activity might be due to the low availability of calcium ions under stress conditions (Liao et al., 2019).

Furthermore, the contents of reducing and non-reducing sugars also followed the trend of a-amylase activity (Figures $1 \mathrm{~b}$ and $\mathrm{c}$ ). The levels of sugars increased gradually with time but sugar concentrations declined under increased concentrations of $\mathrm{Cd}$ stress. Specifically, under the lower concentration of $\mathrm{Cd}$ stress $\left(25 \mathrm{mg} . \mathrm{L}^{-1}\right)$, reducing sugar contents increased by $17 \%, 20 \%$, and $29 \%$ after 72,96 , and $120 \mathrm{~h}$, respectively, whereas, non-reducing sugar levels increased by $8 \%$ and $9 \%$ after 96 and $120 \mathrm{~h}$, respectively, as compared to their respective controls. The statistical analyses indicated that the $\mathrm{Cd}$ treatment and time duration interaction for both reducing and non-reducing sugars was significant. As

a

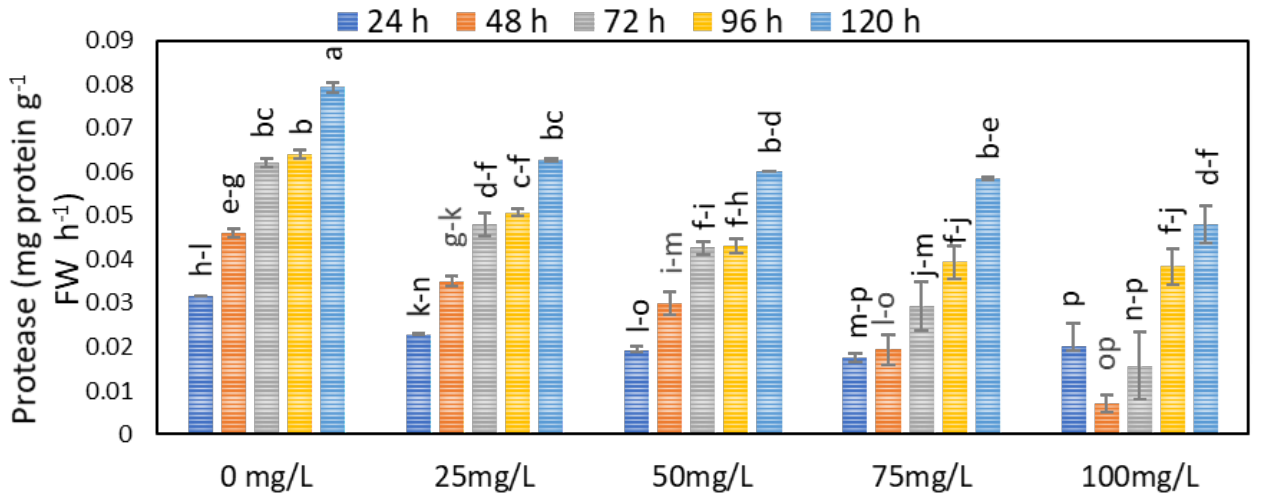

b

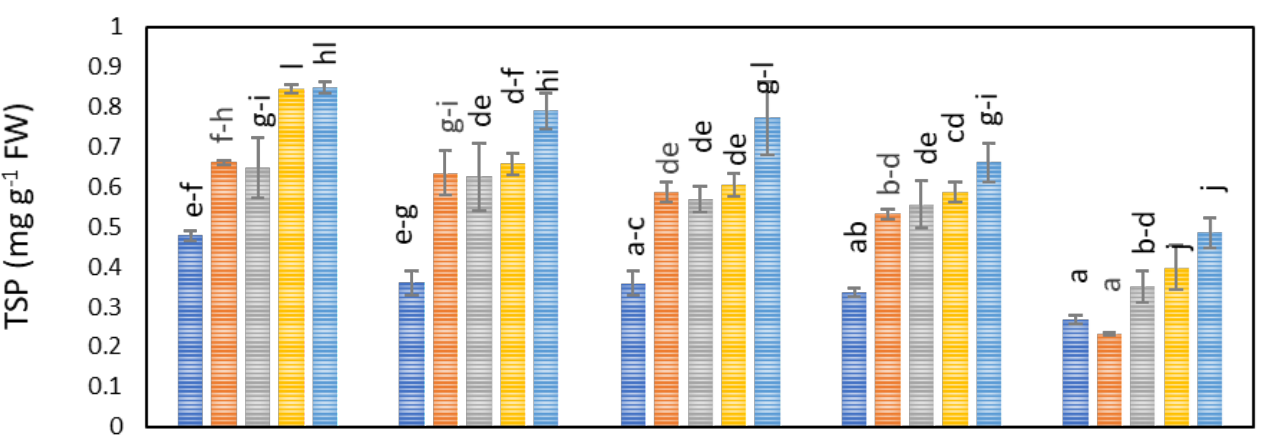

$\mathrm{c}$

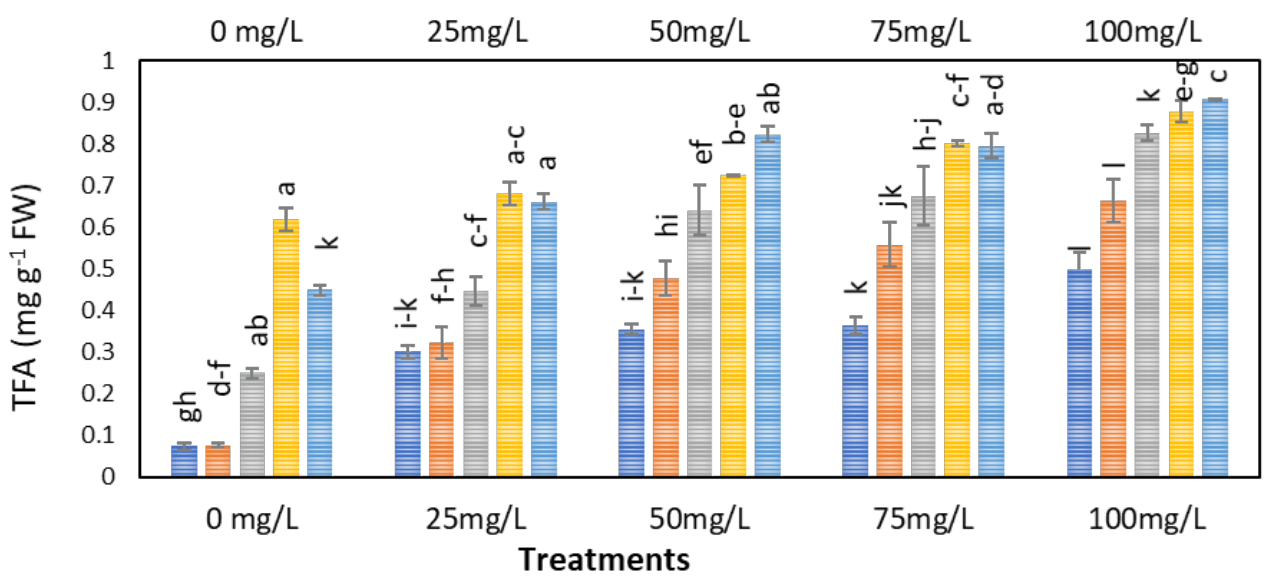

Figure 1. The effect of $\mathrm{Cd}$ and time of application of $\mathrm{Cd}$ on the a) protease activity, b) total soluble protein, and c) total free amino acid contents of germinating seedlings of Vigna radiata. Each bar indicates means of 3 replicates \pm standard error. Different alphabets on bars show non-significant differences among treatments. 
$\alpha$-amylase activity was not fully inhibited under $\mathrm{Cd}$ stress conditions, therefore $\alpha$-amylase might have continued to degrade starch into soluble sugars (reducing \& non-reducing) which further accumulated in the germinating seedlings due to impaired translocation. Our results strengthen this point as $\mathrm{Cd}$ stress decreased the levels of both reducing and non-reducing sugars significantly, but an increasing trend was observed with an increase in time duration and maximum values of soluble sugars were observed at $24 \mathrm{~h}$. Kuriakose and Prasad (2008) also reported that $\mathrm{Cd}$ toxicity in germinating seedlings of Sorghum bicolor impaired hydrolyzing enzyme activities and inserted a negative effect on the translocation of hydrolysis products towards the growing embryonic axis.

\section{Effect of cadmium stress on protease activity}

As depicted in Figure $2 \mathrm{a}$, the proteolytic activity of mungbean seedlings significantly increased with time and the highest was observed at $120 \mathrm{~h}$ after sowing under all cadmium treatments but declined by increasing concentrations of $\mathrm{Cd}$ stress. The highest protease activity was observed in seedlings grown under normal conditions $\left(0 \mathrm{mg} \cdot \mathrm{L}^{-1}\right)$. Whereas,

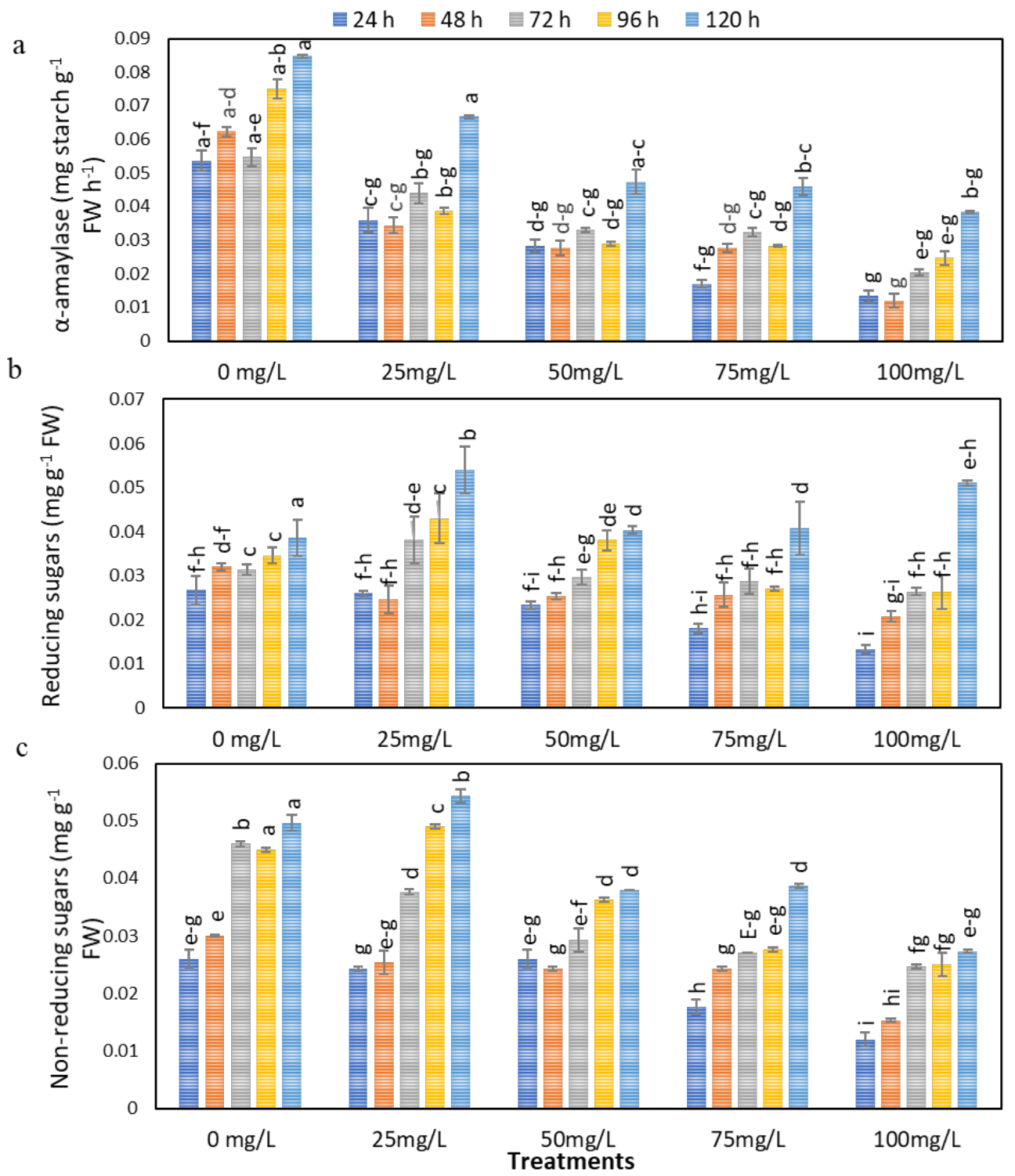

Figure 2. The effect of $\mathrm{Cd}$ and time of application of $\mathrm{Cd}$ on the a) amylase activity, b) reducing sugars, and c) total nonreducing sugars of germinating seedlings of Vigna radiata. Each bar indicate means of 3 replicates \pm standard error. Different alphabets on bars showed non-significant difference among treatments. 
maximum decline (84\%) was observed under $100 \mathrm{mg} \cdot \mathrm{L}^{-1} \mathrm{Cd}$ stress after 48 has compared to control. It was also noted that at $25 \mathrm{mg} \cdot \mathrm{L}^{-1}$ and $50 \mathrm{mg} \cdot \mathrm{L}^{-1} \mathrm{Cd}$ treatment, a sharp decrease in protease activity was observed at the start of germination, such as $29 \%$ and $38 \%$ decline under $25 \mathrm{mg} \cdot \mathrm{L}^{-1}$ and $50 \mathrm{mg} \cdot \mathrm{L}^{-1} \mathrm{Cd}$ treatment respectively at $24 \mathrm{~h}$ as well as $23 \%$ and $34 \%$ decline at $48 \mathrm{~h}$. However, after $48 \mathrm{~h}$ the protease activity started to appear stable.

\section{Soluble protein content}

Total soluble protein content was significantly influenced by $\mathrm{Cd}$ contamination (Figure $2 \mathrm{~b}$ ). The maximum decline (65\%) in protein contents was observed under $100 \mathrm{mg} \cdot \mathrm{L}^{-1} \mathrm{Cd}$ exposure for $48 \mathrm{~h}$. On the contrary, higher values of soluble proteins were observed in mungbean seedlings grown under control conditions $\left(0 \mathrm{mg} \cdot \mathrm{L}^{-1}\right)$. Furthermore, the total soluble protein content was significantly influenced by the duration of germination as protein contents increased with the passage of time and observed maximum after $120 \mathrm{~h}$ of sowing. It is also noted that under $25 \mathrm{mg} \cdot \mathrm{L}^{-1}$ and $50 \mathrm{mg} \cdot \mathrm{L}^{-1} \mathrm{Cd}$ treatments, the protein content of seedlings increased rapidly after $96 \mathrm{~h}$ such as $17 \%$ and $15 \%$ increase was noted as compared to protein content at $96 \mathrm{~h}$. The metabolism of seed protein via proteolytic enzymes is a critical step during seed germination. It has been reported previously that activities of proteolytic enzymes mainly increase during earlier days of germination while protease inhibitors disappeared in this duration (Ali and Alozeiri, 2017). In this regard, reduced activities of hydrolyzing enzymes further hinder the mobilization of stored products. Different proteases are involved in developmental processes, senescence, and mobilization of reserve proteins (Kuriakose and Prasad, 2008). In this study, we observed a decrease in protease activity under increasing $\mathrm{Cd}$ concentration; however, an increasing trend was observed with the time of application of $\mathrm{Cd}$ stress as maximum protease activity was noted at $120 \mathrm{~h}$ under all $\mathrm{Cd}$ concentrations.

\section{Effect of cadmium stress on total free amino acids}

The results presented in Figure $2 \mathrm{c}$ revealed that the total free amino acid (TFA) contents displayed a significant increase upon exposure to $\mathrm{Cd}$ stress, whereas the most pronounced effect was observed at $100 \mathrm{mg}$. $\mathrm{L}^{-1}$ with $69 \%, 29 \%$, and $46 \%$ increase after 72,96 , and $120 \mathrm{~h}$ respectively, as compared to control. Similarly, TFA content also displayed a gradual increase with time. The catalysis of seed proteins further releases free amino acids, which support the biosynthesis of other proteins in the seed endosperm and developing embryo that eventually leads towards germination. Our results also showed a similar trend as the protein levels decreased under $\mathrm{Cd}$ treatment while total free amino acids exhibited a significant increase with time after application of Cd stress. Vassilev and Lidon (2011) reported an increase in some specific amino acids such as aspartic acid, asparagine, proline, leucine, isoleucine, methionine, and valine in two barley cultivars under $\mathrm{Cd}$ stress conditions as compared to control. It might be because some amino acids play a significant role under heavy metal stress conditions, such as proline (Hayat et al., 2012), histidine, and cysteine (Ghori et al., 2019), so the higher accumulation of free amino acids in germinating seedlings is an indication of plant adaptation to stress conditions by stabilizing osmoregulation, metal chelation and signal transduction pathways.

\section{Pearson's Correlation Coefficients}

The correlation coefficients indicated a positive relation among growth traits, i.e., shoot length, root length, fresh weight, and dry weight of shoots and roots (Figure 3 ). The activity of $\alpha$-amylase was positively related, while protease activity was negatively related to all the growth traits. The activity of non-reducing sugar was positively related to fresh biomass while negatively related to protease and total soluble protein. 


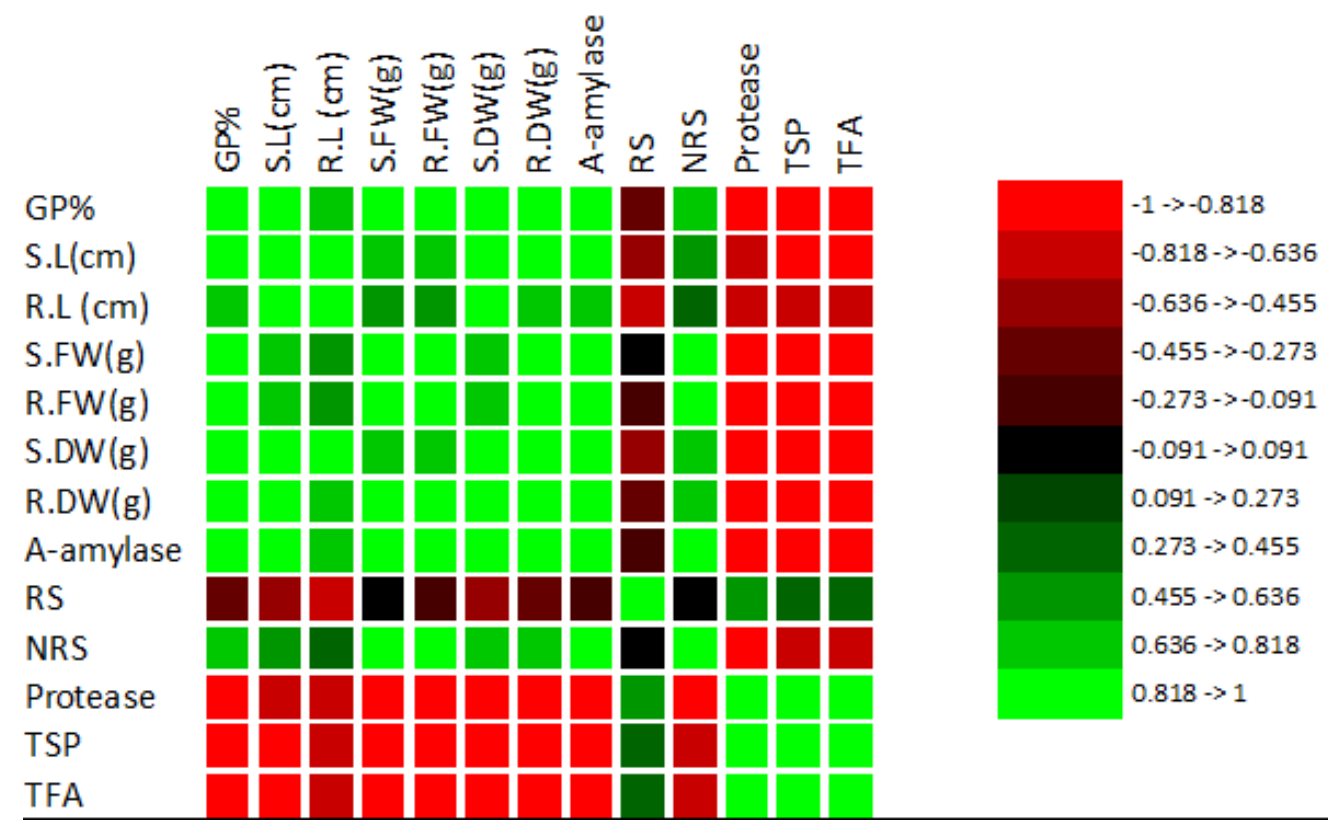

Figure 3. Pearson correlation between different variables of germinating seedlings of Vigna radiata. GP: germination percentage; RS: reducing sugars; NRS: non-reducing sugars; TSP: total soluble proteins; TFA: total free amino acids.

\section{CONCLUSIONS}

Cadmium stress decreased all the germination parameters and activities of hydrolytic enzymes. The highest $\mathrm{Cd}$ level (100 mg. $\left.\mathrm{L}^{-1}\right)$ caused a decrease in germination percentage (27\%), shoot length (63\%), root length (27\%), shoot fresh biomass (28\%), root fresh biomass (61\%), root dry biomass (2-fold), and shoot dry biomass (9-fold) compared to non-treated plants. In addition, total soluble sugars and protein levels declined, while free amino acid level increased under $\mathrm{Cd}$ stress. But the activities of starch hydrolyzing enzyme, total reducing and non-reducing sugar levels, total soluble protein contents, and free amino acids displayed a significant increase with time, but increase was less under $\mathrm{Cd}$ stress. These results showed that $\mathrm{Cd}$ inhibits hydrolytic enzymes and mobilization and translocation of hydrolyzed sugars to embryonic axis which ultimately inhibited seedling growth.

\section{REFERENCES}

AINOUZ, I.I. Preliminary studies on proteins of Vigna sinesis. Anais da Academia Brasileira de Ciências, v.42, n.1, p.97-101, 1970. https://agris.fao.org/agris-search/search.do?recordID=US201302060615

ALI, A.S.; ELOZEIRI, A.A. Metabolic processes during seed germination. Advances in Seed Biology, p. 141-166, 2017.

BASAHI, M. Humic acid improved germination rate, seedling growth and antioxidant system of pea (Pisum sativum L. var. Alicia) grown in water polluted with $\mathrm{CdCl}_{2}$. AIMS Environmental Science, v.8, n.4, p.358-370, 2021. https://aimspress.com/aimspress-data/ aimses/2021/4/PDF/Environ-08-04-23.pdf

BRADFORD, M.M. A rapid and sensitive method for the quantitation of microgram quantities of protein utilizing the principle of protein-dye binding. Analytical Biochemistry, v.72, n.1-2, p.248-254, 1976. https://doi.org/10.1016/0003-2697(76)90527-3

CHRISPEELS, M.J.; VARNER, K.E. Gibberelic acid enhanced synthesis and release of alpha-amylase and ribonuclease by isolated barley aleurone layers. Plant Physiology, v.42, n.3, p.398-406, 1967. https://doi.org/10.1104/pp.42.3.398

DONG, Q.; FANG, J.; HUANG, F.; CAI, K. Silicon amendment reduces soil cd availability and Cd uptake of two Pennisetum species. International Journal of Environmental Research and Public Health, v.16, n.9, 1624, 2019. https://doi.org/10.3390/ijerph16091624 
DUBOIS, M.; GILLES, K. A.; HAMILTON, J. K.; REDERS, P. A.; SMITH, F. Colorimetric method for determination of sugars and related substances. Analytical Chemistry, v.28, p.350-356, 1956. https://doi.org/10.1021/ac60111a017

GHANI, A. Effect of cadmium toxicity on the growth and yield components of mungbean [Vigna radiata (L.) Wilczek]. World Applied Sciences Journal, v.8, p.26-29, 2010.

GHORI, N.H.; GHORI, T.; HAYAT, M.Q.; IMADI, S.R.; GUL, A.; ALTAY, V.; OZTURK, M. Heavy metal stress and responses in plants. International Journal of Environmental Science and Technology, v.16, n.3, p.1807-1828, 2019. https://doi.org/10.1007/s13762-019-02215-8

HAMILTON, P.B.; VAN SLYKE, D.D.; LEMISH, S. The gasometric determination of free amino acids in blood filtrates by the ninhydrincarbon dioxide method. Journal of Biological Chemistry, v.150, p.231-250, 1943.

HASSAN, M.; ISRAR, M.; MANSOOR, S.; HUSSAIN, S. A.; BASHEER, F.; AZIZULLAH, A.; UR REHMAN, S. Acclimation of cadmiuminduced genotoxicity and oxidative stress in mung bean seedlings by priming effect of phytohormones and proline. Plos One, v.16, n.9, 2021. https://doi.org/10.1371/journal.pone.0257924

HAYAT, S.; HAYAT, Q.; ALYEMENI, M. N.; WANI, A. S.; PICHTEL, J.; AHMAD, A. Role of proline under changing environments: a review. Plant Signaling \& Behavior, v.7, n.11, p.1456-1466, 2012. https://doi.org/10.4161/psb.21949

HE, J.Y.; REN, Y.F.; CHENG, Z.H.U.; JIANG, D.A. Effects of cadmium stress on seed germination, seedling growth and seed amylase activities in rice (Oryza sativa). Rice Science, v.15, n.4, p.319-325, 2008. https://doi.org/10.1016/S1672-6308(09)60010-X

HE, J.Y.; REN, Y.F.; PAN, X.B.; YAN, Y.P.; ZHU, C.; JIANG, D. Salicylic acid alleviates the toxicity effect of cadmium on germination, seedling growth, and amylase activity of rice. Journal of Plant Nutrition and Soil Science, v.173, p.300-305, 2010. https://doi. org/10.1002/jpln.200800302

IRFAN, M.; AHMAD, A.; HAYAT, S. Effect of cadmium on the growth and antioxidant enzymes in two varieties of Brassica juncea. Saudi Journal of Biological Sciences, v.21, n.2, p.125-131, 2014. https://doi.org/10.1016/j.sjbs.2013.08.001

KALAI, T.; BOUTHOUR, D.; MANAI, J.; BEN KAAB, L.B.; GOUIA, H. Salicylic acid alleviates the toxicity of cadmium on seedling growth, amylases and phosphatases activity in germinating barley seeds. Archives of Agronomy and Soil Science, v.62, p.892-904, 2016. https://doi.org/10.1080/03650340.2015.1100295

KALAI, T.; KHAMASSI, K.; SILVA, J.A.T.; GOUIA, H.; BETTAIEB BEN-KAAB, L. Cadmium and copper stress affect seedling growth and enzymatic activities in germinating barley seeds. Archives of Agronomy and Soil Science, v.60, n.6, p.765-783, 2014. https://doi. org/10.1080/03650340.2013.838001

KAUR, N.; KAUR, P.; GUPTA, A.K. Inter organ comparison of amylases and starch content in mungbean seedlings. Acta Physiologea Plantarum, v.23, p.429-435, 2001. https://doi.org/10.1007/s11738-001-0053-6

KURIAKOSE, S.V.; PRASAD, M.N.V. Cadmium stress affects seed germination and seedling growth in Sorghum bicolor (L.) Moench by changing the activities of hydrolyzing enzymes. Plant Growth Regulation, v.54, p.143-156, 2008. https://doi.org/10.1007/s10725007-9237-4

KRIVOROTOVA, T.; SEREIKAITE, J. Determination of fructan exohydrolase activity in the crude extracts of plants. Electronic Journal of Biotechnology, v.17, n.6, p.329-333, 2014. http://dx.doi.org/10.1016/j.ejbt.2014.09.005

LIAO, S.M.; LIANG, G.E.; ZHU, J.; LU, B.O.; PENG, L.X.; WANG, Q.Y.; HUANG, R.B. Influence of calcium ions on the thermal characteristics of $\alpha$-amylase from thermophilic Anoxybacillus sp. GXS-BL. Protein and Peptide Letters, v.26, n.2, p.148-157, 2019. https://doi.org/ $10.2174 / 0929866526666190116162958$

LOWRY, O.H.; ROSEBROUGH, N.J.; FARR, A.L.; RANDALL, R.J. Protein measurement with the Folin phenol reagent. Journal of Biological Chemistry, v.193, p.265-275, 1951.

MILLER, G.L. Use of dinitrosalicylic acid reagent for determination of reducing sugar. Analytical Chemistry, v.31, n.3, p.420-428, 1959. https://doi.org/10.1021/ac60147a030

QIN, S.; LIU, H.; NIE, Z.; RENGEL, Z.; GAO, W.; LI, C.; ZHAO, P. Toxicity of cadmium and its competition with mineral nutrients for uptake by plants: A review. Pedosphere, v.30, n.2, p.168-180, 2020. https://doi.org/10.1016/S1002-0160(20)60002-9

RAHOUI, S.; CHAOUI, A.; EL FERJANI, E. Membrane damage and solute leakage from germinating pea seed under cadmium stress. Journal of Hazardous Materials, v.178, p.1128-1131, 2010a. https://doi.org/10.1016/j.jhazmat.2010.01.115 
RAHOUI, S.; CHAOUI, A.; EL FERJANI, E. Reserve mobilization disorder in germinating seeds of Vicia faba L. exposed to cadmium. Journal of Plant Nutrition, v.33, p.809-817, 2010b. https://doi.org/10.1080/01904161003654055

SANAL, F.; SEREN, G.; GU“NER, U. Effects of arsenate and arsenite on germination and some physiological attributes of barley Hordeum vulgare L. Bulletin of Environmental Contamination and Toxicology, v.92, n.4, p.483-489, 2014. https://doi.org/10.1007/ s00128-014-1214-9

VASSILEV, A.; LIDON, F. Cd induced membrane damages and changes in soluble protein and free amino acid contents in young barley plants. Emirates Journal of Food and Agriculture, p.130-136, 2011.

VIJAYARAGAVAN, M.; PRABHAHAR, C.; SURESHKUMAR, J.; NATARAJAN, A.; VIJAYARENGAN, P.; SHARAVANAN, S. Toxic effect of cadmium on seed germination, growth and biochemical contents of cowpea (Vigna unguiculata L.) plants. International Multidisciplinary Research Journal, v.1, n.5, p.1-6, 2011.

YAN, D.; DUERMEYER, L.; LEOVEANU, C.; NAMBARA, E. The functions of the endosperm during seed germination. Plant and Cell Physiology, v.55, n.9, p.1521-1533, 2014. https://doi.org/10.1093/pcp/pcu089 use, distribution, and reproduction in any medium, provided the original work is properly cited. 